Check for updates

Montreal, Canada

Cite this as: BMJ 2021;373:n1643 http://dx.doi.org/10.1136/bmi.n1643 Published: 25 June 2021

\title{
Covid-19: Hunger spreads and food prices soar amid pandemic, warns UN food agency
}

\section{Owen Dyer}

The covid-19 pandemic has sent food prices soaring around the world, the United Nations World Food Programme (WFP) has said.

The number of people assessed as facing the imminent possibility of starvation without food assistance now stands at 41 million, up from 27 million in 2019, according to the joint international classification system used by most aid agencies. ${ }^{1}$ While those are classed as level 4 (emergency) cases, four countries-Ethiopia, Madagascar, South Sudan, and Yemen-are currently seeing level 5 (catastrophe) conditions in some areas, meaning that people are already starving to death.

"I am heartbroken at what we're facing in 2021. We now have four countries where famine-like conditions are present," WFP's director David Beasley told the aid agency's executive board this week. "Meanwhile 41 million people are literally knocking on famine's door. If you look at the numbers, it's just tragic-these are real people with real names."

Burkina Faso and Nigeria in recent months have also seen local pockets declared level 5 catastrophes. The country with the largest number of people facing extreme food insecurity is the Democratic Republic of Congo. But conditions in Ethiopia were bad and worsening even before war broke out in Tigray and assessing the food situation there now is not possible.

Hunger has also spread in wealthier countries like South Africa, as spiking food prices collided with falling incomes, driven downwards by the pandemic and its restrictions, which have hit informal economies especially hard. Enforcement of lockdowns has been strict in many African countries, with widespread reports of police abuses.

Outdoor food markets, which have been closely linked to the world's worst covid-19 death rate in Peru, ${ }^{2}$ have been hit both as sources of food and of income. Farmers have sometimes struggled to obtain seed and tools.

Food prices around the world are at their highest levels in a decade, on average about $40 \%$ higher than last year across a range of basic foodstuffs, according to the WFP. Global prices of maize, the world's most common cereal and a Latin American staple, are up more than $80 \%$ from last year.

In El Salvador, Guatemala, and Honduras, food insecurity has reached levels more commonly associated with sub-Saharan Africa, as covid restrictions combined with two hurricanes last November to devastate local economies. There, as in much of the world, the agricultural cycle means that the WFP's warning comes at the time of greatest danger, when last year's harvest is nearly exhausted but this year's is still two to four months off. Summer is the leanest time for most subsistence farmers.

In Afghanistan, as across much of Africa, poor rainfall and huge locust numbers will mean disappointing yields this year. Economies that have proved fragile in the face of covid have also seen their currencies tumble, making food imports prohibitively expensive for many in Lebanon, Nigeria, Sudan, Venezuela, and Zimbabwe.

Mass starvation is still preventable through normal relief channels, Beasley said. But, he warned, "I want to emphasise just how bad it is out there. Today, 41 million people are literally knocking on famine's door. The price to reach them is about $\$ 6 \mathrm{bn}(£ 4.3 \mathrm{bn}$; $\left.€_{5} \mathrm{bn}\right)$. We need funding and we need it now.

"In Somalia in 2011, 260 ooo people died of hunger-and by the time the famine was actually declared half of that number had already died. We can't debate the numbers when people need our help now."

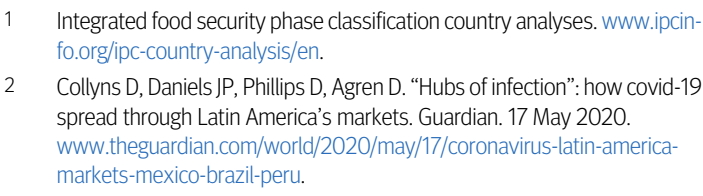

This article is made freely available for use in accordance with BMJ's website terms and conditions for the duration of the covid-19 pandemic or until otherwise determined by BMJ. You may use, download and print the article for any lawful, non-commercial purpose (including text and data mining) provided that all copyright notices and trade marks are retained. 